\title{
PENGEIMBANGAN E-MODUL PEMBELAJARAN PERIKEMBANGAN SOSIAL AUD BERBASIS KARAKTER MENGGUNAKAN SOFTWARE FLIPBOOK MAKER
}

\author{
Wiwik Okta Susilawati' ${ }^{1}$, Andiyanto ${ }^{2}$ \\ ${ }^{1,2}$ Universitas Dharmas Indonesia, Dharmasraya, Sumatra Barat
}

\begin{abstract}
Sumber belajar yang berada dalam sebuah jaringan (daring) di kala pandemi covid-19 ini menjadi momentum bagi dosen untuk membantu mahasiswa PAUD Universitas Dharmas Indonesia beradaptasi dengan pembelajaran di era "kenormalan baru" atau "new normal". Akan tetapi, hal tersebut belum secara maksimal dikembangkan. Sehingga, sampai saat ini mahasiswa belum mendapatkan sumber belajar daring dari dosen, khususnya untuk perkuliahan Perkembangan Sosial AUD. Secara khusus tujuan dari adanya penelitian serta pengembangan ini adalah guna menghasilkan e-modul pembelajaran Perkembangan Sosial AUD berbasis karakter untuk mahasiswa berbantu software flipbook maker. Penelitian ini adalah Research and Development (penelitian berbentuk pengembangan) e-modul Perkembangan Sosial AUD berbasis karakter untuk mahasiswa berbantu software flipbook maker. Penelitian ini menerapkan model ADDIE. Hasil e-modul yang telah dikembangkan dapat diakses pada laman http://online.anyflip.com/iuknb/ixtq/ mobile/index.html. Hasil penelitian memperlihatkan bahwasannya e-modul yang dikembangkan telah memenuhi standar yang valid, praktis serta efektif. Produk e-modul yang telah memenuhi kriteria valid dapat dilihat dari persentase penilaian oleh ahli bahasa dengan capaian 97,8\% (sangat valid), ahli materi yang mencapai 96,7\% (sangat valid) dan ahli media yang mencapai $89,7 \%$ (sangat valid). Sedangkan produk yang telah memenuhi kriteria praktis berdasar dari penilaian oleh dosen pengampu mata kuliah yang mencapai $100 \%$ (sangat praktis) dan penilaian mahasiswa yang mencapai 98,3\% sehingga termasuk dalam kategori sangat praktis. Kemudian produk e-modul yang telah memenuhi kriteria efektif berdasar dari hasil belajar mahasiswa dari segi kognitif. Persentase mahasiswa yang mencapai KKM adalah $100 \%$.
\end{abstract}

Keywords: pengembangan, e-modul berbasis karakter, perkembangan sosial AUD

\section{PENDAHULUAN}

Baru-baru ini dunia digemparkan dengan mewabah dan melonjaknya penyakit secara contagious yang dibawa oleh virus yang bernama Covid-19 (Corona Virus Diseases-19) atau yang sering dikenal dengan sebuah istilah Corona ${ }^{1}$. UNESCO ${ }^{2}$

\footnotetext{
${ }^{1}$ Mona, N. (2020, January-June). Konsep Isolasi dalam Jaringan untuk Meminimalisasi Efek Contagious (Kasus Penyebaran Virus Corona di Indonesia). Jurnal Sosial Humaniora Terapan, 2(2), hlm 117-125

2 Pujiastuti, S. (2020, July 03). Dampak Covid-19 Terhadap Pendidikan Anak. Kedaulatan Rakyat, INSPIRASI UNTUK KEBIJAKAN. Yogyakarta: Survey Meter.
} 
menyebutkan bahwa pandemi Covid-19 mengancam 86.034.287 siswa dari sebuah perguruan tinggi di seluruh penjuru dunia. Oleh sebab itu, pemerintah negara Indonesia dengan tegas mengambil strategi, khususnya dalam bidang pendidikan, yakni belajar dari rumah.

Penetapan kebijakan belajar dari rumah atau belajar dalam jaringan (daring) ini nampaknya menjadi masalah bagi sebagian dosen yang belum pernah memiliki pengalaman mengajar berbasis daring. Padahal semestinya seorang dosen harus selalu mengupdate dan menguupgrade ilmunya. Guna mengatasi hal tersebut, hal-hal yang perlu dipersiapkan dosen, khususnya dosen PAUD di Universitas Dharmas Indonesia (UNDHARI) untuk mengajar berbasis daring adalah salah satunya dengan membuat sumber belajar yang dapat di akses oleh para mahasiswa dimanapun itu dan kapanpun itu tanpa adanya batasan ruang serta waktu. Mengingat mahasiswa PAUD UNDHARI ini berasal dari 3 wilayah besar, yaitu Jambi, Riau dan Sumatera Barat.

Perkembangan Sosial AUD ialah mata kuliah wajib Prodi PG PAUD di Universitas Dharmas Indonesia sehingga mahasiswa harus menempuh serta menguasainya. Guna mendukung terlaksananya perkuliahan tersebut, khususnya di era "new normal" ini peneliti mengembangkan e-modul sebagai bahan ajar yang membantu tercapainya tujuan pembelajaran. E-modul ini dikombinasikan dengan penanaman karakter pada mahasiswa PAUD karena berdasarkan observasi dan wawancara ditemukan beberapa masalah bahwa mereka belum memahami materi perkuliahan dengan baik dan konsep karakter yang sebenarnya, seperti dosen harus menjelaskan materi yang sama berulang kali dan belum tahu makna karakter secara bulat. Padahal mahasiswa PAUD inilah yang esok akan menjadi calon pendidik dalam mengajarkan karakter sejak dini.

Berdasarkan kebutuhan e-modul sebagai sumber belajar yang dikombinasikan dengan penanaman karakter dan kurang maksimalnya pembelajaran daring dalam perkuliahan Perkembangan Sosial AUD, peneliti berinovasi mencari solusi dengan menggunakan teknologi untuk mengembangkan e-modul pembelajaran Perkembangan Sosial AUD berbasis karakter berbantu software flipbook maker. E-modul ini dapat diaplikasikan pada teknologi multimedia pembelajaran sehingga dapat dimanfaatkan menjadi sumber belajar yang lebih menarik dan efektif dari pada modul cetak seperti biasanya.

\section{METODE PENELITIAN}

Menghasilkan produk sumber belajar e-modul perkembangan sosial AUD berbasis karakter untuk mahasiswa berbantu software flipbook maker adalah tujuan dalam penelitian ini. Tempat penelitian akan di laksanakan di Universitas Dharmas Indonesia. Sedangkan waktu pelaksanaan akan direncanakan pada tahun 2021. Karakteristik sasaran penelitian pengembangan e-modul perkembangan sosial AUD berbasis karakter berbantu software flipbook maker adalah mahasiswa Program Studi PAUD semester 4 di Universitas Dharmas Indonesia (UNDHARI). 
Metode yang diterapkan, yaitu metode research and development (penelitian berbentuk pengembangan) yang akan melahirkan sebuah produk yang berupa e-modul pembelajaran berbasis karakter. Model pengembangan yang diterapkan, yakni model ADDIE (meliputi $\mathrm{A}=$ analysis, $\mathrm{D}=$ design, $\mathrm{D}=$ develop, $\mathrm{I}=$ implementation, dan $\mathrm{I}=$ evaluation). Model ADDIE yang dikembangkan dalam lima tahapan ini diuraikan oleh Tegeh (2014) ${ }^{3}$, yaitu (1) analysis (atau analisis), (2) design (atau mendesain), (3) develop (atau mengembangkan), (4) implementation (atau implementasi) dan (5) evaluation (atau evaluasi). Tahapan yang pertama, yakni analisis yang terdiri dari aktivitas menganalisis kebutuhan tiap mahasiswa, menganalisis materi yang akan diajarkan serta menganalisis mahasiswa itu sendiri. Tahapan yang kedua, yakni desain yang terdiri dari perancangan RPS, penentuan tujuan serta pemilihan topik. Tahapan yang ketiga, yakni pengembangan yang terdiri dari proses memproduksi produk yang berupa e-modul. Tahapan yang keempat, yaitu pelaksanaan yang terdiri dari kegiatan penerapan e-modul yang telah siap untuk dimanfaatkan dan tahapan yang kelima, yakni evaluasi yang terdiri dari proses penilaian secara formatif dan sumatif. Prosedur pengembangan e-modul pembelajaran Perkembangan Sosial AUD berbasis karakter digambarkan dalam bagan 1 berikut.

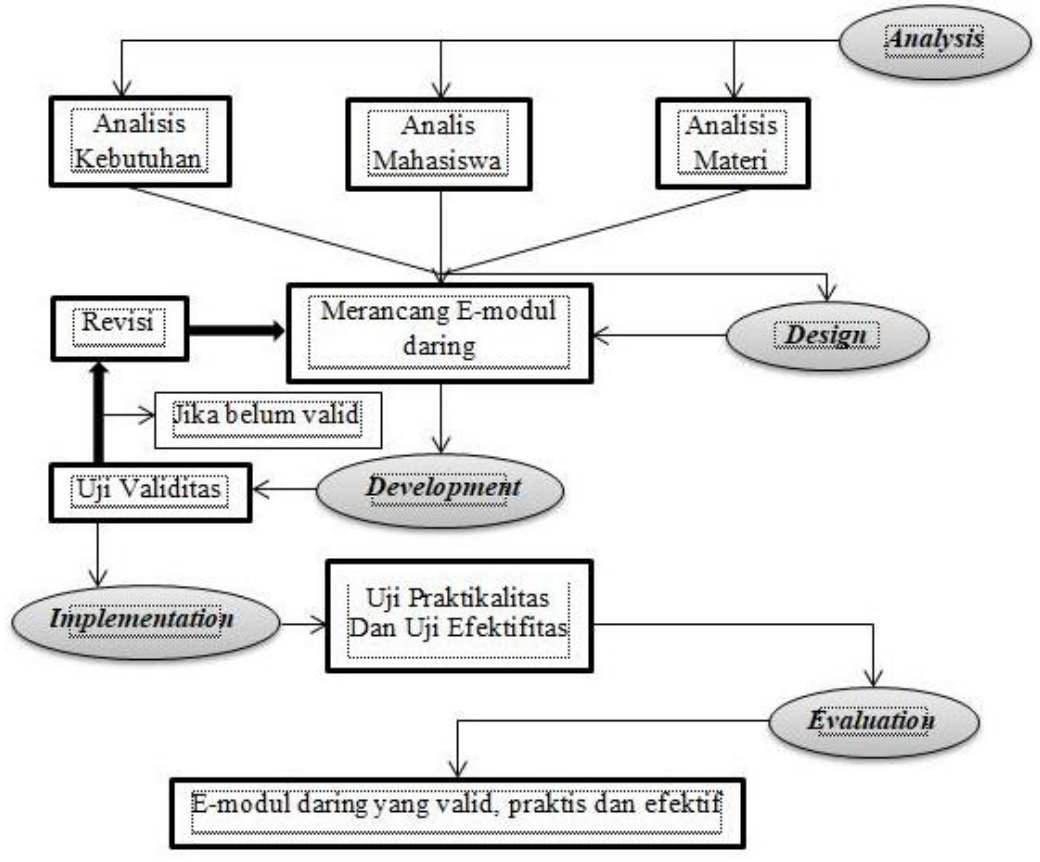

Sebelum e-modul dimanfaatkan, terlebih dahulu dilakukan uji cobakan produknya. Uji coba sebuah produk ini dilaksanakan guna mendapatkan data yang kemudian akan dipergunakan dalam melakukan revisi produk berupa e-modul. Uji cobanya dilaksanakan kepada pengguna produk tentang kualitas e-modul yang sedang dikembangkan. Dalam mengembangkan e-modul pembelajaran Perkembangan Sosial AUD berbasis karakter

${ }^{3}$ Tegeh, I. M. (2014). Model Pengembangan Pengembangan. Yogyakarta: Graha Ilmu, hlm 42. 
ini, uji coba dilakukan pada mahasiswa PG PAUD Universitas Dharmas Indonesia. Data dari hasil uji coba inilah yang akan menjadi dasar dalam merevisi produk e-modul, sehingga produk e-modul yang dihasilkan benar-benar menjadi layak untuk dimanfatkan dalam proses pembelajaran. Pemilihan subjek dilaksanakan dengan purposive sampling.

Validitas produk diuji dengan menggunakan lembar validitas yang diberikan kepada ahli (validator) bersama dengan produk e-modul pembelajaran Perkembangan Sosial AUD berbasis karakter. Sedangkan uji praktikalitas dilakukan dengan menggunakan angket respons dosen dan angket respon mahasiswa. Guna mengetahui keefektifan produk, digunakan instrumen efektifitas yang berupa lembar penilaian pada ranah pengetahuan (kognitif) untuk menentukan hasil belajar mahasiswa. Data yang diperoleh dengan memanfatkan likert scale ${ }^{4}$, seperti pada Tabel 1 di bawah.

Tabel 1. Penskoran memanfaatkan likert scale

\begin{tabular}{|c|c|}
\hline Skor & Kategori \\
\hline 1 & Sangat Tidak Setuju (STS) \\
\hline 2 & Tidak Setuju (TS) \\
\hline 3 & Setuju (S) \\
\hline 4 & Sangat Setuju (SS) \\
\hline
\end{tabular}

Skor yang telah didapat dicari persentasenya dengan menggunakan persamaan $V=$ $\frac{f}{n} \times 100 \%$, dimana $V$ ini merupakan nilai dari validitas/praktikalitas/efektifitas produk emodul, $f$ adalah skor perolehan mahasiswa dan $\mathrm{n}$ adalah skor maksimum mahasiswa. Kategori valid/praktis/efektif produk berdasar nilai akhir yang didapatkan mahasiswa dalam rentang 0-100 seperti pada tabel 2 di bawah.

Tabel 2. Kategori E-Modul

\begin{tabular}{|c|l|}
\hline Interval & \multicolumn{1}{|c|}{ Kategori } \\
\hline$V \leq 20$ & Sangat tidak valid/praktis/efektif \\
\hline $20<V \leq 40$ & Tidak valid/praktis/efektif \\
\hline $40<V \leq 60$ & Kurang valid/praktis/efektif \\
\hline $60<V \leq 80$ & Valid/praktis/efektif \\
\hline$V>80$ & Sangat valid/praktis/efektif \\
\hline
\end{tabular}

Jadi disimpulkan bahwasannya produk e-modul yang dapat dikatakan valid/praktis/efektif apabila persentasenya mencapai $V>60 \%$.

${ }^{4}$ Riduwan. (2018). Belajar Mudah Penelitian untuk Guru, Karyawan dan Peneliti Pemula. Bandung: Alfabeta, hlm 116. 


\section{KAJIAN TEORI}

\section{A. Konsep Pengembangan E-Modul}

Research and Development (penelitian pengembangan) adalah sebuah cara dan strategi dalam memperbaiki berbagai problem yang ada, khususnya pada dunia pendidikan ${ }^{5}$. Pengembangan merupakan suatu metode yang menjadi pemutus dari adanya kesenjangan antara penelitian terapan dengan penelitian dasar. Penelitian ini membentuk suatu siasat kebijakan yang dapat dilihat serta dapat menciptakan produk/hasil secara sistematis, matang dengan melalui tahapan-tahapan dalam proses sebuah development dan memerlukan teori dari sebuah design untuk menciptakan inovasi terbaru6 . Tidak hanya itu, pengertian lain Research and Development (penelitian pengembangan) ialah sebuah aktivitas penelitian yang dimanfaatkan guna melahirkan suatu produk tertentu dengan mengkaji keefektifan dari adanya produk tersebut. Berdasarkan beberapa argumen di atas, dapat disimpulkan bahwasannya pengembangan adalah suatu strategi dalam mencipta suatu produk dengan melalui tahapan-tahapan secara sistematis dan terencana ${ }^{7}$.

Selanjutnya, makna e-modul adalah sumber belajar yang berisi pokok bahasan, strategi belajar serta langkah mengevaluasi yang disusun secara runtut guna menarik serta mencapai kompetensi sesuai dengan kurikulum secara elektronik ${ }^{8}$. Kemudian pengertian e-modul adalah modul yang dikombinasikan dengan teknologi serta berisi penggalanpenggalan kata dengan pertanyaan pada setiap penggalan ${ }^{9}$.

Sedangkan pengertian pembelajaran dalam sebuah jaringan (daring), yakni pembelajaran yang menggunakan jaringan internet guna memunculkan berbagai jenis interaksi dalam pembelajaran ${ }^{10}$. Pembelajaran daring merubah pembelajaran konvensional (pembelajaran berbasis tatap muka) menjadi sistem pembelajaran dengan tidak bertatap muka secara langsung karena memanfaatkan teknologi sebagai platform untuk melangsungkan kegiatan pembelajaran ${ }^{11}$.

\footnotetext{
5 Asmara, A. P. (2015, February). Pengembangan Media Pembelajaran berbasis Audio Visual tentang Pembuatan Koloid. Jurnal Ilmiah Didaktika, 15(2), hlm 156-178.

${ }^{6}$ Muldiyana, N. I. (2018, April). Pengembangan Modul Cetak Pada Mata Pelajaran Produktif Teknik Komputer Dan Jaringan Di SMK Negeri 2 Watampone. Jurnal Teknologi Pendidikan, 20(1).

${ }^{7}$ Sugiyono. (2015). Metode Penelitian Pendidikan Pendekatan Kualitatif,Kuantitatif dan R\&D. Bandung: Alfabeta, hlm 407.

${ }^{8}$ Ismi Laili, G. U. (2019, October). Efektivitas Pengembangan E-Modul Project Based Learning Pada Mata Pelajaran Instalasi Motor Listrik. Jurnal Imiah Pendidikan dan Pembelajaran, 3(3), hlm 306-315.

${ }^{9}$ Samiasih, R. (2017). Pengembangan E-module mata pelajaran ilmu Pengetahuan alam pokok bahasan interaksi makhluk hidup dengan lingkungannya. Jurnal Edcomtech, 2(2), hlm 119-124.

${ }^{10}$ Ali Sadikin, A. H. (2020). Pembelajaran di Tengah Wabah Covid-19. BIODIK: Jurnal Ilmiah Pendidikan Biologi, 6(2), hlm 214-224.

${ }^{11}$ Oktafia Ika Handarini, S. S. (2020). Pembelajaran Sebagai Upaya Study From Home (SFH) Selama Pandemi Covid 19. Jurnal Pendidikan Administrasi Perkantoran (JPAP), 8(3), hlm 496-503.
} 
Berdasarkan dari beberapa pendapat ini dapat disimpulkan bahwasannya pengembangan e-modul daring dalam penelitian ini ialah strategi dalam mencipta suatu produk berbasis teknologi yang dapat diakses melalui jaringan dengan tahapan-tahapan secara runtut dan terencana guna menggapai kompetensi yang telah sesuai dengan kurikulum guna mengurangi kejenuhan mahasiswa dalam belajar.

\section{B. Perkembangan Sosial Anak Usia Dini}

Perkembangan sosial AUD ialah suatu rangkaian proses belajar untuk mencapai kematangan dalam sebuah hubungan secara sosial dan mengarahkan sang anak pada kemandirian dan ketampilan dalam mengembangkan hubungan sosialnya ${ }^{12}$. Tidak hanya itu, pengertian lain perkembangan sosial AUD adalah kemampuan untuk melakukan korelasi dengan orang lain ${ }^{13}$.

Berdasarkan beberapa pengertian di atas, maka perkembangan sosial AUD ialah proses belajar mengajar yang harus dilalui oleh sang anak untuk berkomunikasi dengan orang lain guna menghasilkan pengalaman baru dalam situasi sosial yang akan mereka hadapi.

\section{Karakter}

Pada dasarnya karakter telah melekat pada setiap personal, yang tercermin dari pola pikir serta sikap dalam kehidupan sehari-hari. Karakter dipengaruhi oleh faktor bawaan maupun faktor lingkungan ${ }^{14}$. Apabila diibaratkan karakter merupakan sebuah mustika hidup yang mampu membedakan manusia dengan binatang ${ }^{15}$. Karakter ialah nilai yang sangat mendasar dalam mempengaruhi kepribadian seseorang, baik hereditas maupun lingkungan dan terwujud dalam suatu perilaku sehari-hari ${ }^{16}$. Pendidikan karakter tercipta dari adanya tuntutan karena karakter bukan hanya sekadar deretan ilmu pengetahuan tetapi juga aksi positif dari ilmu yang telah didapat ${ }^{17}$.

Berdasarkan beberapa pendapat di atas, karakter dalam penelitian ini merupakan suatu nilai yang sangat fundamen dalam mempengaruhi kepribadian seseorang karena karakter bukan hanya sekadar deretan pengetahuan tetapi juga aksi positif dari pengetahuan yang sudah didapat dan dimiliki.

\footnotetext{
12 Musyarofah. (2017, Juny). Pengembangan Aspek Sosial Anak Usia Dini di Taman Kanak-kanak ABA IV Mangli Jember Tahun 2016. INJECT: Interdisciplinary Journal of Communication, 2(1), hlm 99-122.

13 Nurjannah. (2017, Juny). Mengembangan Kecerdasan Sosial Emosional Anak Usia Dini melalui Keteladanan. HISBAH: Jurnal Bimbingan Konseling dan Dakwah Islam, 14(1), hlm 50-61.

${ }^{14}$ Kokom Komalasari, D. S. (2017). Pendidikan Karakter: Konsep dan Aplikasi Living Values Education. Bandung: PT. Refika Aditama, hlm 1.

15 Kurniawan, S. (2017). Pendidikan Karakter: Konsepsi \& Implementasinya secara Terpadu di Lingkungan Keluarga, Sekolah, Perguruan Tinggi \& Masyarakat. Yogyakarta: Ar-Ruzz Media, hlm 1.

${ }^{16}$ Putry, R. (2018, March). Nilai Pendidikan Karaker Anak di Sekolah Perspektif Kemendiknas. Gender Equality: Internasional Journal of Child and Gender Studies, 4(1), hlm 39-54.

17 Maharani Ramadhanti, M. S. (2019, January). Pembentukan Karakter dalam Pembelajaran BCCT (Beyond Center and Circle Time). Jurnal Educate, 4(1), hlm 9-17.
} 


\section{Software Flipbook Maker}

Software Flipbook Maker ini ialah sebuah aplikasi yang mendukung pembelajaran dan didalamnya diselipkan animasi-animasi seperti gerak, video dan juga audio ${ }^{18}$. Tidak hanya itu, pengertian lain dari Software Flipbook Maker adalah suatu aplikasi yang mampu memberikan efek flip bolak balik dengan menghasilkan produk yang bisa disebarluaskan dalam format Shock Wave Flash (SWF) dan juga dalam format Hyper Text Markup Language (HTML) ${ }^{19}$.

Jadi berdasarkan beberapa pendapat di atas pengertian Software Flipbook Maker dalam penelitian ini adalah sebuah aplikasi yang mampu memberikan efek bolak balik pada tampilan modul sehingga menghasilkan produk yang bisa disebarluaskan dalam format Shock Wave Flash (SWF) dan juga dalam format Hyper Text Markup Language (HTML).

\section{E. Kerangka Konseptual}

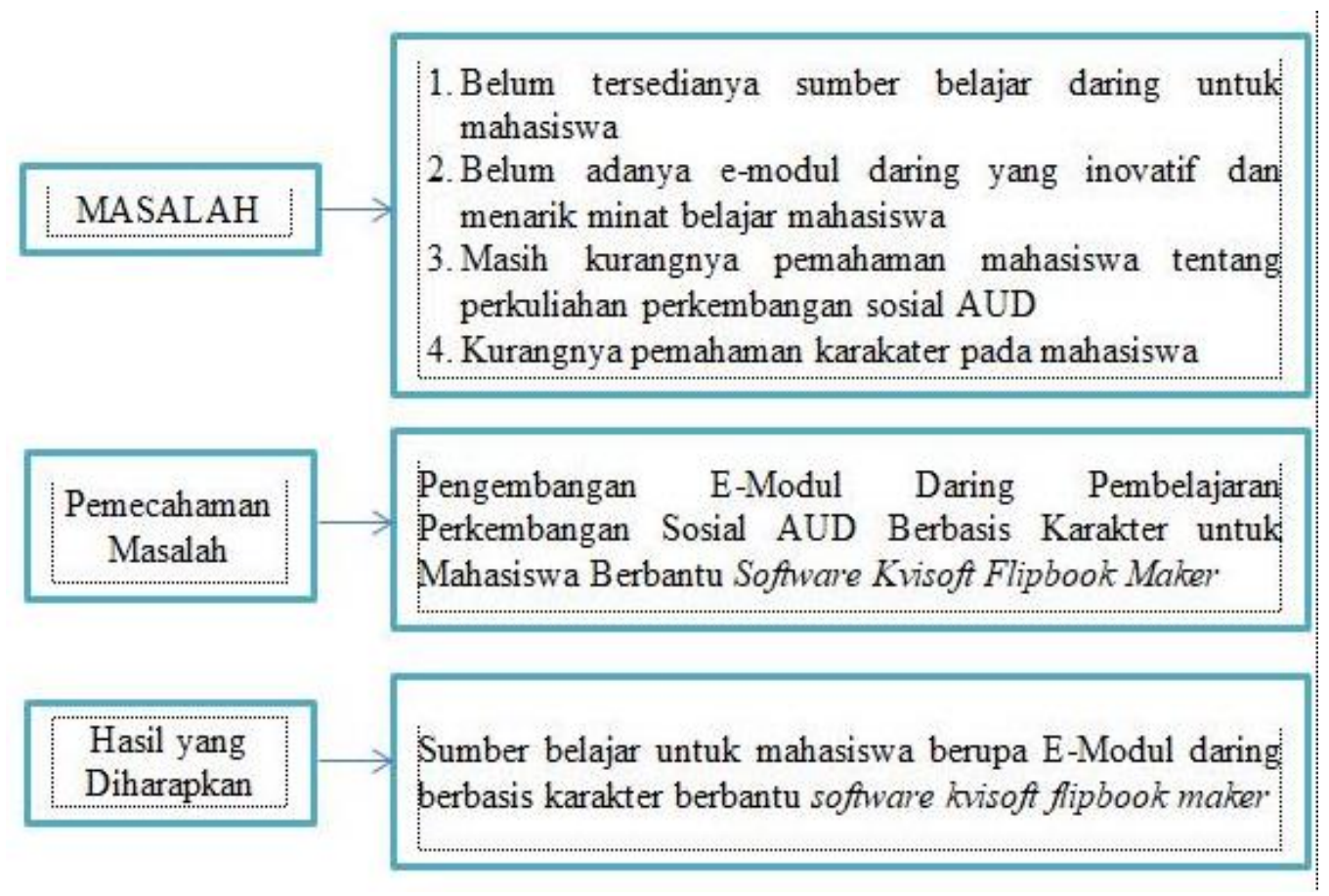

\footnotetext{
${ }^{18}$ Edi Wibowo, D. D. (2018). Pengembangan Bahan Ajar Menggunakan Aplikasi Kvisoft Flipbook Maker Materi Himpunan. Desimal: Jurnal Matematika, 1(2), hlm 147-156.

${ }^{19}$ Qalbi Shanaz Anandari, E. F. (2019, July-December). Development of Electronic Module: Student Learning Motivation Using the Application of Ethnoconstructivism-Based Flipbook Kvisoft. Jurnal Pedagogik, 6(2), hlm 417-436.
} 


\section{F. Road Map Penelitian}

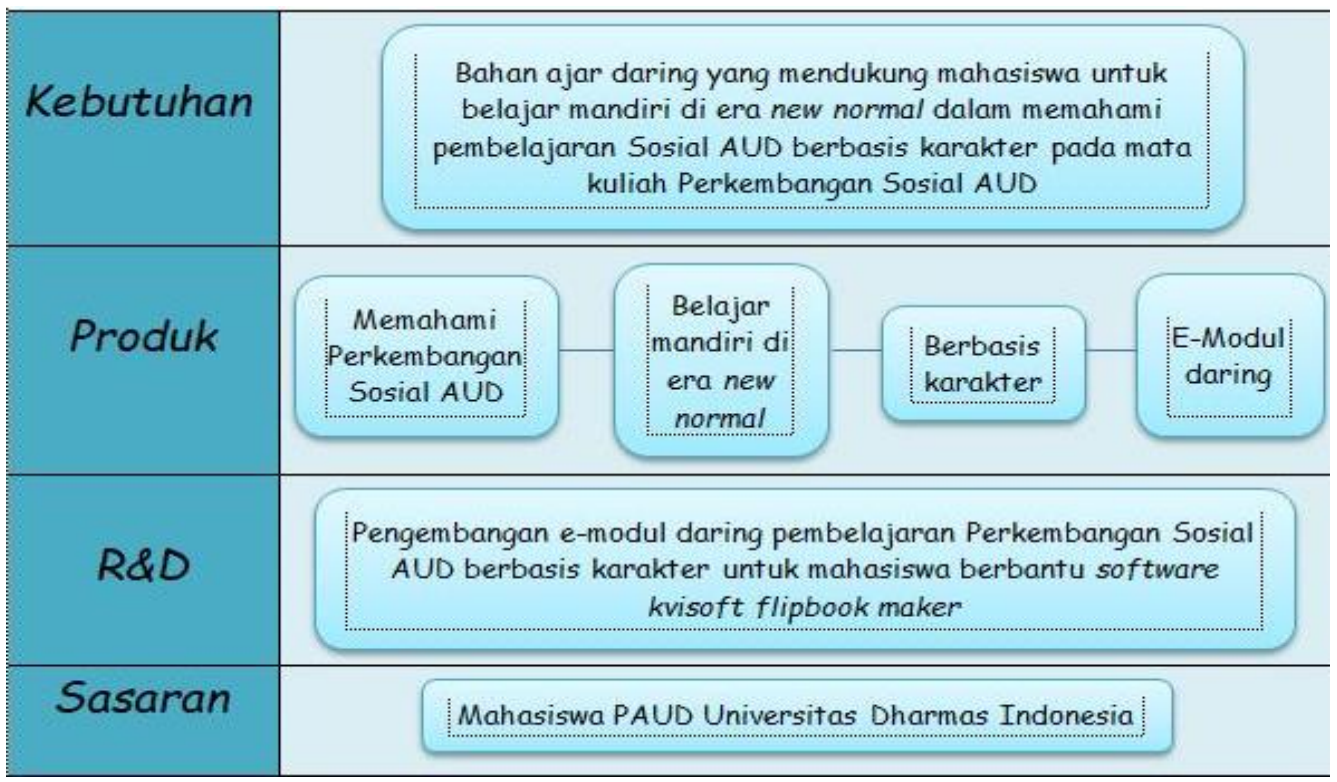

\section{HASIL PENELITIAN DAN PEMBAHASAN}

Pengembangan e-modul perkembangan sosial AUD berbasis karakter ini memanfaatkan ADDIE dengan tahapan-tahapan yang dimulai dari analisis, perancangan, pengembangan dan implementasi serta evaluasi. Adapun hasil dari tahapan tersebut adalah berikut ini:

\section{Tahapan Analyze (Analisis)}

Penelitian ini diawali dengan menganalisa kebutuhan mahasiswa PG PAUD terhadap materi perkuliahan Perkembangan Sosial AUD. Data analisis kebutuhan diperoleh dari penyebaran angket kebutuhan mahasiswa. Angket kenutuhan mahasiswa disebarkan ke 9 orang mahasiswa PG PAUD semester 4 Universitas Dharmas Indonesia yang telah mengontrak mata kuliah Perkembangan Sosial AUD. Hasil penyebaran angket kebutuhan mahasiswa ini dapat dilihat pada Tabel 3 dibawah.

Tabel 3. Analisis Kebutuhan Mahasiswa

\begin{tabular}{|c|l|l|}
\hline No & \multicolumn{1}{|c|}{ Aspek yang Dinilai } & Persentase Jawaban \\
\hline 1 & $\begin{array}{l}\text { Apakah Saudara menyukai materi ajar } \\
\text { perkuliahan Perkembangan Sosial AUD? }\end{array}$ & $\bullet$ Ya (44\%) \\
\hline 2 & $\begin{array}{l}\text { Apakah mata kuliah Perkembangan Sosial } \\
\text { AUD ini mata kuliah dengan materi yang sukar } \\
\text { dipahami pada perkuliahan daring ini? }\end{array}$ & $\bullet$ Ya $(89 \%)$ \\
\hline
\end{tabular}




\begin{tabular}{|c|c|c|}
\hline 3 & $\begin{array}{l}\text { Apakah Saudara mempunyai bahan ajar untuk } \\
\text { mata kuliah Perkembangan Sosial AUD? }\end{array}$ & $\begin{array}{l}\text { - } \text { Ya }(67 \%) \\
\text { - } \text { Tidak }(33 \%)\end{array}$ \\
\hline 4 & $\begin{array}{l}\text { Apakah bahan ajar yang Saudara manfaatkan } \\
\text { sudah mencukupi pemahaman Saudara dalam } \\
\text { memahami mata kuliah tersebut? }\end{array}$ & $\begin{array}{l}\text { - } \text { Ya }(22 \%) \\
\text { - } \text { Tidak }(78 \%)\end{array}$ \\
\hline 5 & $\begin{array}{l}\text { Apakah Saudara membutuhkan suatu bahan } \\
\text { ajar tambahan/pelengkap guna menunjang } \\
\text { pembelajaran daring pada mata kuliah } \\
\text { tersebut? }\end{array}$ & $\begin{array}{l}\text { - } \text { Ya }(100 \%) \\
\text { - Tidak }(0 \%)\end{array}$ \\
\hline 6 & $\begin{array}{l}\text { Apakah Saudara pernah memanfaatkan e- } \\
\text { modul dalam memahami mata kuliah } \\
\text { Perkembangan Sosial AUD? }\end{array}$ & $\begin{array}{ll}\text { - } & \text { Ya }(0 \%) \\
\text { - } & \text { Tidak }(100 \%) \\
\end{array}$ \\
\hline 7 & $\begin{array}{l}\text { Jika Saudara tidak pernah memanfaatkannya, } \\
\text { bagaimana menurut Saudara apakah e-modul } \\
\text { pembelajaran dibutuhkan dalam mempelajari } \\
\text { mata kuliah Perkembangan Sosial AUD? }\end{array}$ & $\begin{array}{l}\text { - } \text { Ya }(100 \%) \\
\text { - } \text { Tidak }(0 \%)\end{array}$ \\
\hline 8 & $\begin{array}{l}\text { Konten tambahan seperti apa yang Saudara } \\
\text { inginkan ada/muncul di dalam e-modul? }\end{array}$ & $\begin{array}{l}\text { - Bahasa yang mudah di } \\
\text { cerna (44\% } \\
\text { - Gambar yang menarik } \\
(56 \%)\end{array}$ \\
\hline 9 & $\begin{array}{l}\text { Apakah Saudara tertarik untuk memanfaatkan } \\
\text { e-modul untuk mempalajari mata kuliah } \\
\text { Perkembangan Sosial AUD? }\end{array}$ & $\begin{array}{l}\text { - } \quad \text { Ya }(100 \%) \\
\text { - } \text { Tidak }(0 \%)\end{array}$ \\
\hline 10 & $\begin{array}{l}\text { Apakah Saudara tertarik memanfaatkan e- } \\
\text { modul pembelajaran untuk mata kuliah } \\
\text { Perkembangan Sosial AUD yang } \\
\text { dikombinasikan dengan kata-kata mutiara } \\
\text { tentang karakter? }\end{array}$ & $\begin{array}{l}\text { - } \text { Ya }(100 \%) \\
\text { - } \text { Tidak }(0 \%)\end{array}$ \\
\hline 11 & $\begin{array}{l}\text { Menurut Saudara, apa-saja saja unsur penting } \\
\text { dalam materi ajar yang membutuhkan e-modul } \\
\text { untuk memahaminya? }\end{array}$ & $\begin{array}{l}\text { - } \text { Alasan } \\
(100 \%)\end{array}$ \\
\hline 12 & $\begin{array}{l}\text { Pada mata kuliah Perkembangan Sosial AUD } \\
\text { terdapat salah satu materi pembelajaran } \\
\text { strategi dan metode perkembangan sosial } \\
\text { AUD. Menurut Saudara apakah materi ajar } \\
\text { tersebut akan cocok untuk dibuatkan e-modul } \\
\text { pembelajaran? }\end{array}$ & $\begin{array}{l}\text { - } \quad \text { Ya }(100 \%) \\
\text { - } \text { Tidak }(0 \%)\end{array}$ \\
\hline 13 & $\begin{array}{l}\text { Apakah Saudara dalam proses belajar } \\
\text { mengajar secara daring dosen yang mata } \\
\text { kuliah Perkembangan Sosial AUD sudah } \\
\text { memanfaatkan menggunakan strategi yang } \\
\text { tepat? }\end{array}$ & $\begin{array}{l}\text { - } \text { Ya }(89 \%) \\
\text { - } \text { Tidak }(11 \%)\end{array}$ \\
\hline
\end{tabular}




\begin{tabular}{|l|l|l|}
\hline 14 & $\begin{array}{l}\text { Menurut Saudara, apakah strategi tersebut } \\
\text { perlu untuk dimanfaatkan dalam proses } \\
\text { perkuliahan pada mata kuliah Perkembangan } \\
\text { Sosial AUD? }\end{array}$ & $\bullet$ Tidak (0\%) \\
\hline
\end{tabular}

Dari hasil data dari analisis kebutuhan yang diisi oleh mahasiswa di atas terhadap pengembangan suatu bahan ajar e-modul dinyatakan bahwa bahan ajar yang dimanfaatkan pada mata kuliah pengembangan sosial AUD belum mampu memenuhi kebutuhan mahasiswa. Berdasarkan hasil angket yang didapat sebagian besar mahasiswa PG PAUD memerlukan bahan ajar tambahan/pelengkap yang dapat mendukung proses belajar mengajar. Mahasiswa menjelaskan bahwasannya mereka juga menyetujui dengan adanya pengembangan bahan ajar baru, khususnya pada materi perkembangan sosial AUD dalam bentuk e-modul. Hampir seluruh mahasiswa mengungkapkan bahwa belum pernah memanfaatkan bahan ajar e-modul dalam proses perkuliahan yang berlangsung. Sehingga e-modul ini akan menarik minat mahasiswa untuk menggunakannya dalam proses pembelajaran, khususnya e-modul yang dikombinasikan dengan penanaman karakter. Mengingat kembali kondisi terkini terkait pandemi covid-19 dan rendahnya karakter generasi muda penerus bangsa maka e-modul berbasis bisa dijadikan sarana belajar daring yang diterapkan oleh pemerintah. Oleh sebab itu meskipun pembelajaran tidak dilaksanakan secara tatap muka, e-modul menjadi salah satu alternatif yang bisa dipakai.

Dalam pengembangan e-modul mahasiswa menyatakan bahwa strategi pembelajaran diperlukan agar pembelajaran tidak membosankan dan mahasiswa tertarik dalam pembelajaran perkembangan sosial AUD. Berdasarkan penjabaran analisis di atas dapat disimpulkan bahwa mahasiswa membutuhkan bahan ajar tambahan dalam memahami mata kuliah perkembangan sosial AUD sehingga membutuhkan solusi dengan cara mengembangkan sebuah bahan ajar yang berupa e-modul. Banyak sekali bahan ajar berbentuk modul salah satunya, yaitu e-modul. E-modul ini ialah salah satu bahan ajar yang berbentuk elektronik yang bisa digunakan baik dalam pembelajaran daring dan juga luring.

Selain analisis kebutuhan mahasiswa, dilakukan juga analisis materi yang bertujuan untuk menyesuaikan materi yang diajarkan dengan kurikulum. Berdasarkan kurikulum perguruan tinggi (KPT) berbasis KKNI tentang CP dan Sub-CP pada prodi PG PAUD semester 4, khususnya mata kuliah Perkembangan Sosial AUD, materi yang dipelajari adalah konsep dasar perkembangan sosial emosional AUD, mekanisme dan fungsi sosial emosi AUD, dimensi perkembangan sosial emosi AUD, karakteristik perkembangan sosial emosi, faktor-faktor pengaruh perkembangan sosial emosi, pendekatan dalam perkembangan sosial emosi, hubungan perkembangan sosial emosi anak dengan mental, assesmen/penilaian dan evaluasi perkembangan sosial emosi, problematika sosial emosi AUD, strategi penanganan masalah sosial emosi, simulasi permainan dalam 
meningkatkan kecerdasan sosial emosi dan strategi serta metode perkembangan sosial emosi AUD.

2. Tahapan Design (Perancangan)

Hasil perancangan yang telah diakukan oleh peneliti adalah mendesain sebuah emodul yang akan dikembangkan. Pada tahapan design ini peneliti melakukan perancangan materi ajar, perancangan RPS dan perancangan lembar penilaian validitas, praktikalitas dan efektifitas. Materi yang dikembangan pada e-modul sesuai dengan hasil analisis kebutuhan mahasiswa. RPS yang dikembangkan dibagi menjadi 14 pertemuan berbasis karakter. Untuk lembar penilaian, peneliti merancang instrumen berupa lembar validitas, praktikalitas dan efektifitas. Lembar validitas terdiri dari validitasi isi (materi), penyajian dan bahasa. Lembar praktikalitas terdiri dari sejumlah pernyataan yang diisi oleh dosen dan mahasiswa PG PAUD. Selain itu, lembar uji efektifitas terdiri dari soal evaluasi materi.

3. Tahapan Develop (Pengembangan)

E-modul yang telah dirancang sebelumnya akan dilanjutkan dengan aktivitas pemvalidasian oleh validator yang telah ditetapkan peneliti sesuai bidangnya masingmasing. Validasi e-modul dilaksanakan oleh sembilan orang validator, yaitu 3 ahli dalam materi, ahli dalam bahasa dan ahli dalam teknologi pendidikan/media. Data lembar penilaian oleh validator dideskripsikan serta dianalisis juga secara kualitatif maupun kuantitatif, yaitu dengan menentukan persentase serta perhitungan dengan menggunakan skala Likert $^{20}$. Hasil pengolahan data validitas e-modul dari aspek materi, penyajian dan bahasa berturut-turut disajikan pada Tabel 4, Tabel 5 serta Tabel 6.

\footnotetext{
${ }^{20}$ Riduwan. (2018). Belajar Mudah Penelitian untuk Guru, Karyawan dan Peneliti Pemula. Bandung: Alfabeta, hlm 116.
} 
Tabel 4. Hasil Validitas E-modul dari Aspek Materi

\begin{tabular}{|c|l|c|c|c|}
\hline \multirow{2}{*}{ No } & \multicolumn{1}{|c|}{ Aspek yang Dinilai } & \multicolumn{3}{c|}{ Validator } \\
\cline { 3 - 5 } & \multicolumn{1}{|c|}{ Validator 1 } & Validator 2 & Validator 3 \\
\hline 1 & Kesesuaian materi dengan RPSnya & 5 & 5 & 5 \\
\hline 2 & $\begin{array}{l}\text { Kesesuaian materinya dengan tujuan } \\
\text { pembelajaran }\end{array}$ & 5 & 5 & 5 \\
\hline 3 & Kemudahan untuk memahami materi & 5 & 5 & 5 \\
\hline 4 & Cakupan materinya & 5 & 5 & 5 \\
\hline 5 & Kedalaman materinya & 5 & 5 & 4 \\
\hline 6 & $\begin{array}{l}\text { Latihan soal dengan tujuan pembelajaran } \\
\text { harus konsisten }\end{array}$ & 5 & 4 & 4 \\
\hline 7 & Pemberian umpan balik terhadap hasil belajar & 5 & 5 & 4 \\
\hline 8 & Kejelasan pembahasan materi & 5 & 5 & 5 \\
\hline 9 & Kejelasan simulasi & 4 & 4 & 4 \\
\hline 10 & Penyampaian materi & 5 & 5 & 5 \\
\hline 11 & Penggunaan bahasa baku & 5 & 5 & 5 \\
\hline 12 & Kemudahan penggunaan bahasa & 5 & 5 & 5 \\
\hline 13 & Interakvitas dengan pengguna & 5 & 5 & 5 \\
\hline 14 & $\begin{array}{l}\text { Meningkatkan perhatian mahasiswa dalam } \\
\text { belajar }\end{array}$ & 5 & 5 & 5 \\
\hline Jumlah & 69 & 68 & 66 \\
\hline Kriteria & $98,6 \%$ & $97,1 \%$ & $94,3 \%$ \\
\hline Rata-Rata & \multicolumn{2}{|c|}{$\mathbf{9 6 , 7 0 \%}$} \\
\hline
\end{tabular}

Berdasarkan Tabel 4, diidentifikasi bahwa persentase keseluruhan untuk aspek materi adalah 96,70\%. Berdasarkan teknik analisis data validitas penilaian aspek yang dinilai termasuk kriteria sangat valid. Hasil validasi ini menggambarkan bahwa materi pada e-modul telah sesuai dengan capaian pembelajaran serta subtansi pada materi emodul sudah benar.

Tabel 5. Hasil Validitas E-modul dari Aspek Penyajian/Media

\begin{tabular}{|c|l|c|c|c|}
\hline \multirow{2}{*}{ No } & \multirow{2}{*}{ Aspek Yang Dinilai } & \multicolumn{3}{c|}{ Validator } \\
\cline { 3 - 5 } & & Validator 1 & Validator 2 & Validator 3 \\
\hline 1 & Sistematis Penyajian & 5 & 5 & 5 \\
\hline 2 & Keruntutan penyajian & 5 & 5 & 5 \\
\hline 3 & Bagian Pendahuluan & 5 & 5 & 5 \\
\hline 4 & Bagian Isi & 5 & 5 & 5 \\
\hline 5 & Bagian Penutup & 5 & 5 & 5 \\
\hline
\end{tabular}




\begin{tabular}{|c|c|c|c|c|}
\hline \multirow[t]{2}{*}{6} & \multicolumn{4}{|l|}{ Ukuran Emodul: } \\
\hline & $\begin{array}{l}\text { a) Kesesuaian Ukuran Emodul } \\
\text { dengan Standar ISO }\end{array}$ & 5 & 5 & 5 \\
\hline \multirow[t]{4}{*}{8} & \multicolumn{4}{|l|}{ Desain Cover: } \\
\hline & a) Tata letaknya & 4 & 5 & 5 \\
\hline & $\begin{array}{l}\text { b) Komposisi serta Ukuran dari } \\
\text { Unsur Tata Letaknya }\end{array}$ & 4 & 5 & 5 \\
\hline & c) Huruf & 4 & 5 & 5 \\
\hline \multirow[t]{5}{*}{9} & \multicolumn{4}{|l|}{ Desain Isi Emodul: } \\
\hline & a) Pencerminan dari Isi Emodul & 5 & 5 & 5 \\
\hline & $\begin{array}{l}\text { b) Keharmonisan Tata Letak } \\
\text { Emodul }\end{array}$ & 4 & 5 & 5 \\
\hline & $\begin{array}{l}\text { c) Kelengkapan Tata Letak } \\
\text { Emodul }\end{array}$ & 5 & 4 & 5 \\
\hline & d) Tipografi Isi Emodul & 5 & 5 & 4 \\
\hline \multicolumn{2}{|c|}{ Jumlah } & 61 & 64 & 64 \\
\hline \multicolumn{2}{|c|}{ Kategori } & $87 \%$ & $91 \%$ & $91 \%$ \\
\hline \multicolumn{2}{|c|}{ Rata-Rata } & \multicolumn{3}{|c|}{$\begin{array}{c}\mathbf{8 9 , 7 \%} \\
\text { (Sangat Valid) }\end{array}$} \\
\hline
\end{tabular}

Tabel 5 menunjukkan bahwa aspek dari segi penyajian/media pada e-modul yang valid berdasarkan teknik analisa data validitas dengan persentase keseluruhan $89,7 \%$. Dapat diartikan bahwa penyajian pada e-modul memiliki desain tempilan serta penyajian e-modul yang disesuaikan dengan unsur-unsur e-modul dan penyajian e-modul disesuaikan dengan karakteristik berbasis karakter.

Tabel 6. Hasil Validitas E-modul dari Aspek Bahasa dan Keterbacaan E-modul

\begin{tabular}{|c|c|c|c|c|}
\hline \multirow{2}{*}{ No } & \multirow{2}{*}{ Aspek yang Dinilai } & \multicolumn{3}{|c|}{ Validator } \\
\hline & & Validasi 1 & Validasi 2 & Validasi 3 \\
\hline 1 & $\begin{array}{l}\text { Keseuaian dengan Tingkat } \\
\text { Perkembangan Intektual }\end{array}$ & 5 & 5 & 5 \\
\hline 2 & $\begin{array}{l}\text { Kesesuaian Emodul dengan Tingkat } \\
\text { Perkembangan Sosial Emosional AUD }\end{array}$ & 5 & 5 & 5 \\
\hline 3 & Keterbacaan Pesan & 5 & 5 & 5 \\
\hline 4 & Ketepatan Kaidah Bahasa & 5 & 5 & 4 \\
\hline 5 & Keruntutan dan Keterpaduan antar Bab & 5 & 4 & 5 \\
\hline 6 & $\begin{array}{l}\text { Keruntutan dan Keterpaduan antar } \\
\text { Paragraf }\end{array}$ & 5 & 5 & 5 \\
\hline & Jumlah & 30 & 29 & 29 \\
\hline & Kriteria & $100 \%$ & $96,7 \%$ & $96,7 \%$ \\
\hline
\end{tabular}




\begin{tabular}{|c|c|}
\hline Rata-Rata & $\begin{array}{c}\mathbf{9 7 , 8 \%} \\
\text { (Sangat Valid) }\end{array}$ \\
\hline
\end{tabular}

Tabel 6 ini menunjukkan bahwa aspek dari segi bahasa dan terbacaan pada e-modul yang valid dengan persentase keseluruhannya, yakni 97,8\%. Dapat diartikan bahwa bahasa dan keterbacaan pada e-modul memiliki kejelasan tentang informasi serta kesesuaian bahasa dengan kaidah Bahasa Indonesia yang baik serta yang benar.

Berdasarkan hasil validasi materi, penyajian/media dan bahasa, e-modul berbasis karakter untuk mahasiswa PG PAUD dikategorikan sangat valid.

4. Tahapan Implementation (Implementasi)

Pada tahap implementasi dilakukan uji praktikalitas setelah materi ajar dikembangkan dan diuji kevalidannya. Hasil praktikalitas diperoleh dari lembar praktikalitas yang dibagikan ke dosen dan mahasiswa Pendidikan G PAUD semester 4 yang sedang menempuh mata kuliah Perkembangan Sosial AUD. Berikut ini hasil uji praktikalitas pada Tabel 7 dan Tabel 8.

Tabel 7. Hasil Uji Praktikalitas E-modul oleh Dosen Pengampu Mata Kuliah

\begin{tabular}{|c|l|c|}
\hline No & \multicolumn{1}{|c|}{ Pernyataan } & Dosen \\
\cline { 2 - 3 } 2 & $\begin{array}{l}\text { Tampilan cover e-modul menjadikan Saudara tertarik untuk belajar } \\
2\end{array}$ & $\begin{array}{l}\text { Dahasan telah menarik perhatian Saudara untuk mempelajari materi } \\
\text { lebih mendalam }\end{array}$ \\
\hline 3 & $\begin{array}{l}\text { Tujuan belajar yang ada sudah memudahkan Saudara untuk } \\
\text { mengetahuai kemampuan apa saja yang harus dipunyai setelah } \\
\text { mengikuti aktivitas pembelajaran }\end{array}$ & 5 \\
\hline 4 & $\begin{array}{l}\text { Materi disajikan dengan tujuan belajar } \\
\text { materi ajar telah meningkatkan pemahaman Saudara tentang }\end{array}$ & 5 \\
\hline 5 & $\begin{array}{l}\text { Rangkuman mengukur } \\
\text { pemahaman materi yang sudah dipelajari Saudara }\end{array}$ & 5 \\
\hline 7 & $\begin{array}{l}\text { Bahasa yang dipakai mudah dipahami mahasiswa } \\
\text { Kistematika penyajian materi memudahkan Saudara memahami } \\
\text { seluruh materi secara bertahap-tahap. }\end{array}$ & $\begin{array}{c}\text { 100\% } \\
\text { (Sangat } \\
\text { Praktis) }\end{array}$ \\
\hline
\end{tabular}

Berdasarkan Tabel 7, maka hasil uji praktikalitas yang dinilai oleh dosen pengampu mata kuliah Perkembangan Sosial diperoleh nilai 100\%, yang artinya e-modul sangat praktis untuk digunakan di kelas PG PAUD. 
Tabel 8. Hasil Uji Praktikalitas E-modul oleh Mahasiswa

\begin{tabular}{|c|c|c|c|c|c|c|c|c|c|c|}
\hline \multirow{2}{*}{ No } & \multirow{2}{*}{ Aspek yang Dinilai } & \multicolumn{9}{|c|}{ Mahasiswa } \\
\hline & & M1 & M2 & M3 & M4 & M5 & M6 & M7 & M8 & M9 \\
\hline 1 & 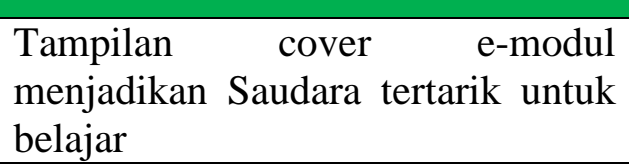 & 5 & 5 & 5 & 4 & 5 & 5 & 5 & 5 & 5 \\
\hline 2 & $\begin{array}{l}\text { Bahasan telah menarik perhatian } \\
\text { Saudara untuk mempelajari materi } \\
\text { lebih mendalam }\end{array}$ & 5 & 5 & 5 & 5 & 5 & 5 & 5 & 5 & 5 \\
\hline 3 & $\begin{array}{l}\text { Tujuan belajar yang ada sudah } \\
\text { memudahkan Saudara untuk } \\
\text { mengetahuai kemampuan apa saja } \\
\text { yang harus dipunyai setelah } \\
\text { mengikuti aktivitas pembelajaran }\end{array}$ & 5 & 5 & 5 & 5 & 5 & 5 & 5 & 5 & 5 \\
\hline 4 & $\begin{array}{l}\text { Materi disajikan dengan tujuan } \\
\text { belajar }\end{array}$ & 5 & 5 & 5 & 5 & 5 & 5 & 5 & 5 & 5 \\
\hline 5 & $\begin{array}{l}\text { Rangkuman telah meningkatkan } \\
\text { pemahaman Saudara tentang materi } \\
\text { ajar }\end{array}$ & 5 & 5 & 4 & 5 & 4 & 5 & 4 & 4 & 5 \\
\hline 6 & $\begin{array}{l}\text { Adanya evaluasi/refleksi membantu } \\
\text { Saudara mengukur pemahaman } \\
\text { materi yang sudah dipelajari }\end{array}$ & 5 & 5 & 5 & 5 & 5 & 5 & 5 & 5 & 5 \\
\hline 7 & $\begin{array}{l}\text { Bahasa yang dipakai mudah } \\
\text { dipahami mahasiswa }\end{array}$ & 5 & 5 & 5 & 5 & 5 & 5 & 4 & 5 & 5 \\
\hline 8 & $\begin{array}{l}\text { Sistematika penyajian materi } \\
\text { memudahkan Saudara memahami } \\
\text { seluruh materi secara bertahap- } \\
\text { tahap. }\end{array}$ & 5 & 5 & 5 & 5 & 5 & 5 & 5 & 5 & 5 \\
\hline \multicolumn{2}{|c|}{ Jumlah } & 40 & 40 & 39 & 39 & 39 & 40 & 38 & 39 & 40 \\
\hline \multicolumn{2}{|c|}{ Kategori } & $\begin{array}{c}100 \\
\%\end{array}$ & $\begin{array}{l}10 \\
0 \%\end{array}$ & $\begin{array}{l}97, \\
5 \%\end{array}$ & $\begin{array}{l}97, \\
5 \% \\
\end{array}$ & $\begin{array}{l}97 \\
5 \% \\
\end{array}$ & $\begin{array}{r}10 \\
0 \% \\
\end{array}$ & $\begin{array}{l}95 \\
\% \\
\end{array}$ & $\begin{array}{l}97, \\
5 \%\end{array}$ & $\begin{array}{c}100 \\
\%\end{array}$ \\
\hline \multicolumn{2}{|c|}{ Rata-Rata } & \multicolumn{9}{|c|}{$\begin{array}{c}\text { 98,3\% } \\
\text { (Sangat Praktis) } \\
\end{array}$} \\
\hline
\end{tabular}

Berdasarkan Tabel 8, maka hasil uji praktikalitas yang dinilai oleh mahasiswa PG PAUD diperoleh nilai 98,3\%, yang artinya e-modul sangat praktis untuk digunakan di kelas PG PAUD.

Jadi, berdasarkan uji praktikalitas yang dinilai oleh dosen pengampu mata kuliah dan mahasiswa didapatkan nilai 99,15\%, yang artinya e-modul sangat praktis untuk digunakan di kelas PG PAUD, khususnya perkuliahan Perkembangan Sosial AUD semester 4 .

5. Tahapan Evaluate (Evaluasi)

Pada tahap evaluasi dilakukan uji efektifitas. Uji efektifitas e-modul Perkembangan Sosial AUD berbasis karakter dilaksanakan sebanyak 2 kali pertemuan. Disetiap 
pertemuannya, mahasiswa diwajibkan untuk mengerjakan setiap tugas-tugas dan latihanlatihan yang ada dalam e-modul tersebut. Kemudian diakhir pertemuan, mahasiswa Pendidikan Guru Pendidikan Anak Usia Dini semester 4 diberikan tes yang terdiri dari 19 soal pilihan ganda. Hasil uji efektifitas bisa dilihat pada Tabel 9 di bawah.

Tabel 9. Hasil Uji Efektifitas

\begin{tabular}{|c|c|c|c|c|c|c|c|c|c|c|c|c|c|c|c|c|c|c|c|c|c|c|}
\hline \multirow{2}{*}{ Mhs } & \multicolumn{19}{|c|}{ Butir Soal } & \multirow{2}{*}{ Jml } & \multirow{2}{*}{ Nilai } & \multirow{2}{*}{ Kriteria } \\
\hline & 1 & 2 & 3 & 4 & 5 & 6 & 7 & 8 & 9 & 10 & 11 & 12 & 13 & 14 & 15 & 16 & 17 & 18 & 19 & & & \\
\hline 1 & 1 & 1 & 1 & 1 & 1 & 1 & 1 & 1 & 1 & 1 & 1 & 1 & 1 & 1 & 1 & 1 & 1 & 1 & 1 & 19 & 100 & Tuntas \\
\hline 2 & 1 & 1 & 1 & 1 & 1 & 1 & 1 & 1 & 1 & 1 & 1 & 1 & 1 & 1 & 1 & 1 & 1 & 1 & 1 & 19 & 100 & Tuntas \\
\hline 3 & 1 & 1 & 1 & 1 & 1 & 1 & 1 & 1 & 1 & 0 & 1 & 1 & 1 & 1 & 1 & 1 & 1 & 1 & 1 & 18 & 94,7 & Tuntas \\
\hline 4 & 1 & 1 & 1 & 1 & 1 & 1 & 1 & 1 & 1 & 0 & 1 & 1 & 1 & 1 & 1 & 1 & 1 & 1 & 1 & 18 & 94,7 & Tuntas \\
\hline 5 & 1 & 1 & 1 & 1 & 1 & 1 & 1 & 1 & 1 & 0 & 1 & 0 & 1 & 1 & 1 & 1 & 1 & 1 & 1 & 17 & 89,5 & Tuntas \\
\hline 6 & 1 & 1 & 1 & 1 & 1 & 1 & 1 & 1 & 1 & 1 & 1 & 1 & 1 & 1 & 1 & 1 & 1 & 1 & 1 & 19 & 100 & Tuntas \\
\hline 7 & 1 & 1 & 1 & 1 & 1 & 1 & 1 & 1 & 1 & 0 & 1 & 1 & 1 & 1 & 1 & 1 & 1 & 1 & 1 & 18 & 94,7 & Tuntas \\
\hline 8 & 1 & 1 & 1 & 1 & 1 & 1 & 1 & 1 & 1 & 0 & 1 & 1 & 1 & 1 & 1 & 1 & 1 & 1 & 1 & 18 & 94,7 & Tuntas \\
\hline 9 & 1 & 1 & 1 & 1 & 1 & 1 & 1 & 1 & 1 & 1 & 1 & 1 & 1 & 1 & 1 & 1 & 1 & 1 & 1 & 19 & 100 & Tuntas \\
\hline \multicolumn{22}{|c|}{ Rata-rata Mahasiswa yang tuntas } & $100 \%$ \\
\hline \multicolumn{22}{|c|}{ Rata-rata Mahasiswa yang tidak tuntas } & $0 \%$ \\
\hline \multicolumn{22}{|c|}{ Rata-rata nilai Mahasiswa } & 96 \\
\hline
\end{tabular}

Dari Tabel 9 berikut, dapat dimaknai bahwa keefektifan e-modul Perkembangan Sosial AUD, yakni mengacu pada hasil belajar mahasiswa. Hal tersebut terlihat dari capaian target yang dicapai oleh mahasiswa. Efektifitas dapat dimaknai sebagai tingkatan suatu keberhasilan dalam pemanfaatan suatu produk, khusunya e-modul. Keefektifan pemanfaatan e-modul Perkembangan Sosial AUD bisa diamati dari hasil belajarnya mahasiswa PG PAUD dengan persentase yang digapai, yakni 100\% tuntas yang kemudian termasuk dalam kategori sangat efektif. Hal ini disempurnakan oleh Riduwan $(2018)^{21}$ yang mengungkapkan bahwa persentase kriteria sangat efektif, yakni $>80 \%$.

${ }^{21}$ (2018). Belajar Mudah Penelitian untuk Guru, Karyawan dan Peneliti Pemula. Bandung: Alfabeta, hlm 89 . 
Dalam hal ini e-modul Perkembangan Sosial AUD termasuk dalam kategori sangat efektif karena mahasiswa dapat menjawab 19 soal tes dengan benar.

\section{SIMPULAN}

Berdasarkan hasil penelitian yang telah dilaksanakan, maka datanya memperlihatkan bahwasannya e-modul berbasis karakter yang dikembangkan telah memenuhi standar valid, praktis dan efektif. Produk e-modul yang memenuhi standar valid dapat diamati dari hasil persentase penilaian oleh ahli bahasa yang mencapai $97,8 \%$ (sangat valid), ahli materi yang mencapai 96,7\% (sangat valid) dan ahli media yang mencapai $89,7 \%$ (sangat valid). Sedangkan produk memenuhi standar kepraktisan berdasar penilaian oleh dosen yang mencapai $100 \%$ (sangat praktis) dan penilaian mahasiswa yang mencapai $98,3 \%$ yang termasuk dalam standar sangat praktis. Kemudian produk memenuhi kriteria efektif berdasar hasil belajar mahasiswa dari segi kognitif. Persentase mahasiswa yang mencapai KKM adalah $100 \%$.

\section{DAFTAR PUSTAKA}

Ali Sadikin, A. H. (2020). Pembelajaran di Tengah Wabah Covid-19. BIODIK: Jurnal Ilmiah Pendidikan Biologi, 6(2), 214-224.

Asmara, A. P. (2015, February). Pengembangan Media Pembelajaran berbasis Audio Visual tentang Pembuatan Koloid. Jurnal Ilmiah Didaktika, 15(2), 156-178.

Edi Wibowo, D. D. (2018). Pengembangan Bahan Ajar Menggunakan Aplikasi Kvisoft Flipbook Maker Materi Himpunan. Desimal: Jurnal Matematika, 1(2), 147-156.

Ismi Laili, G. U. (2019, October). Efektivitas Pengembangan E-Modul Project Based Learning Pada Mata Pelajaran Instalasi Motor Listrik. Jurnal Imiah Pendidikan dan Pembelajaran, 3(3), 306-315.

Kokom Komalasari, D. S. (2017). Pendidikan Karakter: Konsep dan Aplikasi Living Values Education. Bandung: PT. Refika Aditama.

Kurniawan, S. (2017). Pendidikan Karakter: Konsepsi \& Implementasinya secara Terpadu di Lingkungan Keluarga, Sekolah, Perguruan Tinggi \& Masyarakat. Yogyakarta: Ar-Ruzz Media

Maharani Ramadhanti, M. S. (2019, January). Pembentukan Karakter dalam Pembelajaran BCCT (Beyond Center and Circle Time). Jurnal Educate, 4(1), 9-17.

Mona, N. (2020, January-June). Konsep Isolasi dalam Jaringan untuk Meminimalisasi Efek Contagious (Kasus Penyebaran Virus Corona di Indonesia). Jurnal Sosial Humaniora Terapan, 2(2), 117-125 
Muldiyana, N. I. (2018, April). Pengembangan Modul Cetak Pada Mata Pelajaran Produktif Teknik Komputer Dan Jaringan Di SMK Negeri 2 Watampone. Jurnal Teknologi Pendidikan, 20(1).

Musyarofah. (2017, Juny). Pengembangan Aspek Sosial Anak Usia Dini di Taman Kanak-kanak ABA IV Mangli Jember Tahun 2016. INJECT: Interdisciplinary Journal of Communication, 2(1), 99-122.

Nurjannah. (2017, Juny). Mengembangan Kecerdasan Sosial Emosional Anak Usia Dini melalui Keteladanan. HISBAH: Jurnal Bimbingan Konseling dan Dakwah Islam, 14(1), 50-61.

Oktafia Ika Handarini, S. S. (2020). Pembelajaran Sebagai Upaya Study From Home (SFH) Selama Pandemi Covid 19. Jurnal Pendidikan Administrasi Perkantoran (JPAP), 8(3), 496-503.

Pujiastuti, S. (2020, July 03). Dampak Covid-19 Terhadap Pendidikan Anak. Kedaulatan Rakyat, INSPIRASI UNTUK KEBIJAKAN. Yogyakarta: Survey Meter.

Putry, R. (2018, March). Nilai Pendidikan Karaker Anak di Sekolah Perspektif Kemendiknas. Gender Equality: Internasional Journal of Child and Gender Studies, 4(1), 39-54.

Qalbi Shanaz Anandari, E. F. (2019, July-December). Development of Electronic Module: Student Learning Motivation Using the Application of Ethnoconstructivism-Based Flipbook Kvisoft. Jurnal Pedagogik, 6(2), 417-436.

Riduwan. (2018). Belajar Mudah Penelitian untuk Guru, Karyawan dan Peneliti Pemula. Bandung: Alfabeta

Samiasih, R. (2017). Pengembangan E-module mata pelajaran ilmu Pengetahuan alam pokok bahasan interaksi makhluk hidup dengan lingkungannya. Jurnal Edcomtech, 2(2), 119-124.

Sugiyono. (2015). Metode Penelitian Pendidikan Pendekatan Kualitatif, Kuantitatif dan $R \& D$. Bandung: Alfabeta.

Tegeh, I. M. (2014). Model Pengembangan Pengembangan. Yogyakarta: Graha Ilmu. 